特集-プラスチック成型加エにおける压力効果。

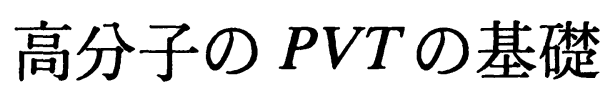

PVT Behavior of Polymers

\title{
扇澤 敏明
}

Ougizawa, Tos hiaki

\begin{abstract}
Pressure-Volume-Temperature (PVT) properties of polymers are very important data for polymer processing, especially, injection molding. The coefficients of thermal expansion in polymers are much larger than those of metals and inorganic materials. So the changing of specific volumes in polymers is very large under processing, i.e., for changes of temperature and pressure. In this paper we describe the relationship between PVT behavior and processing in polymers.
\end{abstract}

[polymers, PVT behavior, polymer processing, glass transition temperature, melting point]

\section{1.はじめに}

高分子の圧力一体積一温度 $(P V T)$ 挙動は、材料 を成形加工する上でなくてはならない基整的なデータ である。高分子の熱膨張係数は金属および無機材料に 比へて著しく大きく、また、圧力による压縮率も大き い。高分子の固化挙動は、主としてガラス化および結 晶化により引き起こされ、液体状態から固体状態（溶 融はその逆）に変化する相転移現象としてとらえるこ とができる。特に、比容積はガラス転移温度 $T_{g}$ あるい は結晶の融点 $T_{m}$ を境界として大きく変化することから、 これらの挙動を詳細に知ることが必要である。つまり、 成形加工工程における加熱・冷却及び加圧・減圧によ る比容積の変化も著しく、大きな残留応力のために反 りや引けが生じることがある。そのために、実際の高 分子の $P V T$ 挙動を正確に測定し、そのデー夕を基に 成形加工に役立てていくことが必要である。特に射出 成形には、高分子の流動特性・熱的な性質亡並んで重 要なデータであるとともに、CAE(Computer Aided Engineering)による成形加工技術の重要な入力データ でもある。

一方、PVT特性は物質の最も基礎的な性質の $1 つ$ であることから、成形加工などの工学的分野だけでな く、系を構成する分子の構造および分子間相互作用な どを解明するための有力な情報を提供する。
ここでは、いくつかの高分子の $P V T$ 挙動を基にし てその特幑と溶融・固化挙動について説明する。そし て、PVT挙動と高分子の成形加工との関係について 述へる。

\section{2. $P V T$ 挙動の测定法}

$P V T$ 挙動の測定法として、3 変数 $P, V, T$ のう ち 1 つを他の 2 変数の関数として測定する直接的測定 法之、密度が変化することによって生じる他の物理量 （浮力、音速、屈折率など）の変化を測定して $P V T$ 関係を明らかにする間接的測定法に大別することがで きる。間接的測定法の方が装置の簡略化に適している か、測定精度の面からは直接的測定法の方が優勢であ ると考えられる。しかし、コンピュータを含むエレク トロニクスの進歩により、間接的測定法の測定精度が 著しく向上してきている。また、直接的測定法におい ても、どのパラメータを一定にして測定するかにより 等圧・等容・等温法といった分類があり、場合によっ ては時間も考虑する必要がある。さらに、圧力媒体で ある液体を用いるかどうかで直接法・間接法といった 分類の仕方もあり、種々様々なものがある[1]。高分子 の $P V T$ 測定については、直接的測定法が主流を占め ていると思われる。市販の装置では、ピストン法ある いはベローズ法により温度と圧力を変化させた場合の

₹152 東京都目黒区大岡山 2-12-1 東京工業大学工学部有機材料工学科

Department of Organic and Polymeric Materials, Tokyo Institute of Technology, 2-12-1 Ookayama, Meguro-ku, Tokyo 152 
(a)
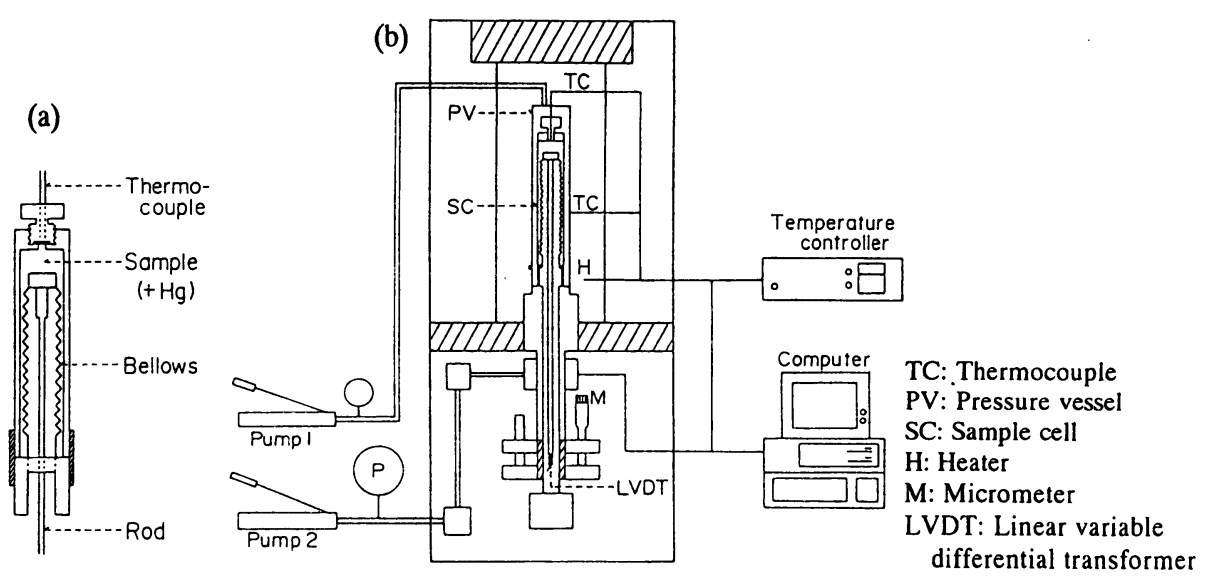

Fig. 1. Apparatus of $P V T$ measurement. (a) sample cell and (b) general drawing[2].

体積変化を測定するものが多い。

Fig. 1 は、ベローズを用いた市販の $P V T$ 測定装置 を示している[2]。測定原理は簡単であり、PVT測定

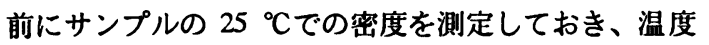
と圧力変化に伴う体積の增堿を測定するものである。 固体用は構造的に液体用と同じであるが、水銀を封入 液体として用い、高分子サンプル量は $1 \sim 1.5 \mathrm{~cm}^{3}$ 程度 である。Fig. 1 (a)に示したサンプルセルは、完全密閒 型でその一端は蛇腹状になっており、サンプルの膨 張・収縮がこの蛇腹の膨張・収縮を引き起こす。これ により、サンプルの体積変化を測定することができる。 完全密閉型であり水銀でキャリブレーションを行うこ とから、ピストン法に比へて精度的に高いと考えられ る。等温モードにおいて、試料の体積は、一定間隔の 圧力（通常 $10 \mathrm{MPa}$ ) ごとに加圧され、加圧中に体積が 測定される。その後、温度を上げて同様にして体積測 定を繰り返すことにより、試料の $P V T$ 挙動が得られ る。また、等圧モードの測定も可能である。この昇温 （降温）・加圧（減圧）は、全てコンピュータにより 制御される。

これらの測定において時間に依存するパラメータも あり注意を要するが、等温モードと等圧モードでの測 定値にほとんど差がないという報告もあることから [3]、上記の等温モードでの測定についても精度的には 問題がないと思われる。

\section{3. 代表的な高分子の $P V T$ 誉㲜}

Fig. $2 \sim 4$ に代表的な高分子の $P V T$ 測定例を示す。 Fig. 2 は未架橋のポリブタジエンゴムの $P V T$ 挙動を

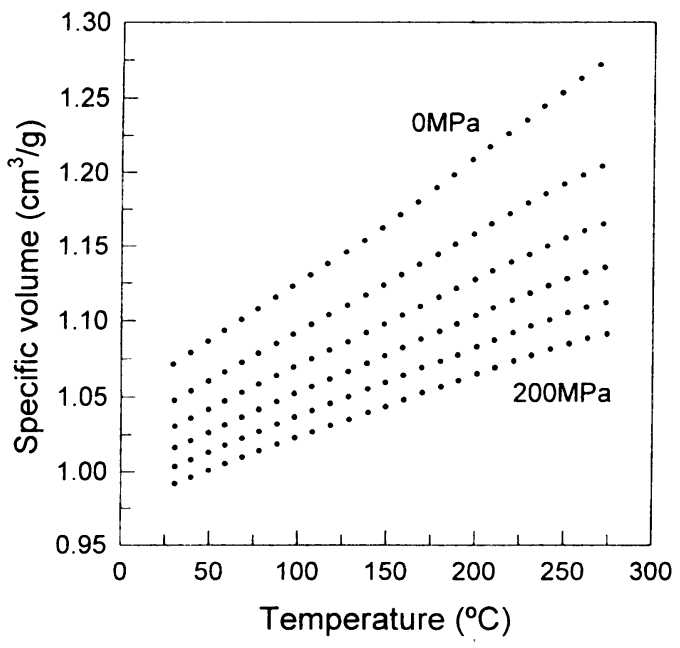

Fig. 2. PVT behavior of polybutadiene[4].

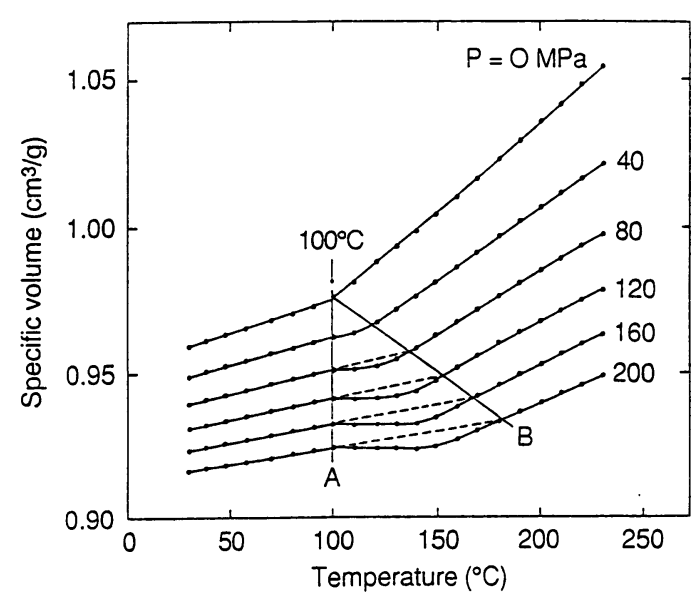

Fig. 3. PVT behavior of polystyrene[5]. 
示している。測定範囲内には $T_{8} や T_{m}$ が存在せず、単 純夜体と同様の挙動を示している。Fig. 3 は非晶性高 分子であるポリスチレン (PS) の $P V T$ 挙動を示して いる。典型的なガラス転移挙動が現れており、 $T_{g}$ の圧 力依存性が見られる（直線 B ）。高分子により巽なる か、 $500 \mathrm{MPa}$ 程度までは、 $T_{\boldsymbol{g}}$ が圧力の增加に対して直 線的に增加し、その割合は $0.2 \sim 0.4{ }^{\circ} \mathrm{C} / \mathrm{MPa}$ 程度であ る。また、溶融状態のみならずガラス状態においてさ え、压力負荷により大きな体皘収縮が起きていること がわかる。Fig.3 は等温モードでの測定結果を示してい るため、直線 A と B との間で体積が下方に䏽らんでい る現象がみられる。これは、常圧での $T_{\boldsymbol{g}}\left(100{ }^{\circ} \mathrm{C}\right)$ 以 上で、いったん溶融状態になったものを加圧すること により再度ガラス化が起きるため、オリジナルのガラ スとは異なる挙動を示したものと考えられる。

Fig. 4 は結晶性高分子であるポリエチレン（PE）の $P V T$ 挙動を示している。結晶性高分子は、非晶性高 分子の $T_{g}$ 前後亡比へて $T_{m}$ 前後で大きな比容積の変化 が生じる。また、 $T_{m}$ の圧力依存性が見られており、高 分子の $T_{m}$ の多くは、压力に対して $0.15 \sim 0.3{ }^{\circ} \mathrm{C} / \mathrm{MPa}$ 程度で上昇する。 $T_{m}$ の圧力依存性は後で記述するよう に相転移前後の熱力学量と密接に関連している。

\section{PVT测定から镜た高分子ガラス}

高分子液体は平衡状態であり、ガラスは非平衡状態 にあると考えられる。高分子ガラスは非平衡であるが ゆえに、熱処理条件の影響を受ける。

Fig. 5 は、分子量(Mw)分布の狭い PS ( $M w=99,000)$ を用いて液体状態から異なる冷却速度でガラス化させ た試料を同じ昇温速度 $\left(4{ }^{\circ} \mathrm{C} / \mathrm{min}\right) て ゙ P V T$ 測定(等圧モ 一ド）を行った結果を示している。ゆっくりと冷却さ れた試料は、ガラス状態で比容積が小さくなっており、 体積緩和が起こったものと考えられる。この試料は、 より高い温度でガラス転移を起こし、体積の不連続な 変化を示す。この体積の不連続な変化は、エンタルピ 一緩和に対応するもの之考えられる。また、Fig. 6 は、 同じ試料の等圧モードで履歴を与えた場合の測定結果 を示している。压力一定で、高温の液体 (平衡) 状態 から始めると同じ冷却・昇温速度で測定する限り、V$T$ 曲線は完全に重なる（10、100 MPaでそれぞれ A-B C、D-E 上をたどる）。Cで $200 \mathrm{MPa}$ まで昇圧し $(\mathrm{C} \rightarrow \mathrm{D})$ 、 保圧したまま室温まで泠却し $(\mathrm{D} \rightarrow \mathrm{E})$ 、それを $10 \mathrm{MPa}$ に戻した場合 $(\mathrm{E} \rightarrow \mathrm{F}) 、 A$ に戻らず $\mathrm{F}$ となる。つまり、 高密度ガラスが形成され、元のガラスと比へると $1 \%$

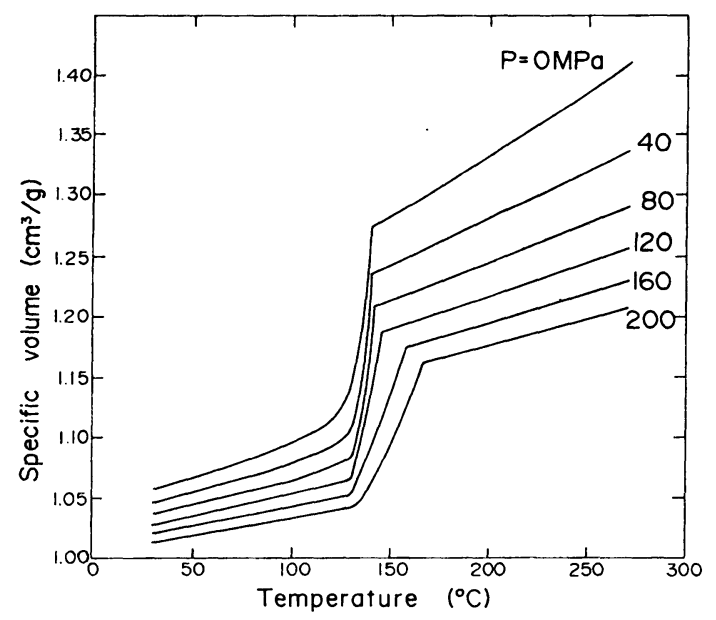

Fig. 4. $P V T$ behavior of polyethylene[4].

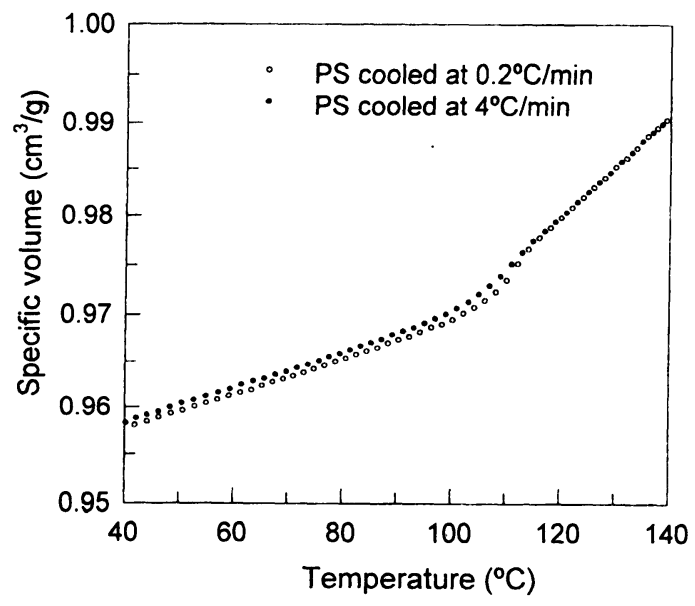

Fig. 5. $V$ - $T$ curves of glassy PS formed with different cooling rate. Heating rate is $4{ }^{\circ} \mathrm{C} / \mathrm{min}[4]$.

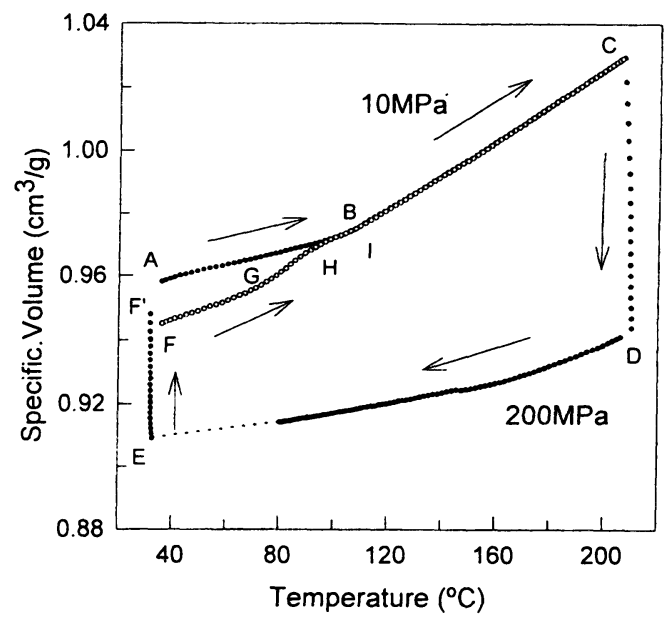

Fig. 6. $P V T$ behavior of densified PS glass[6]. 


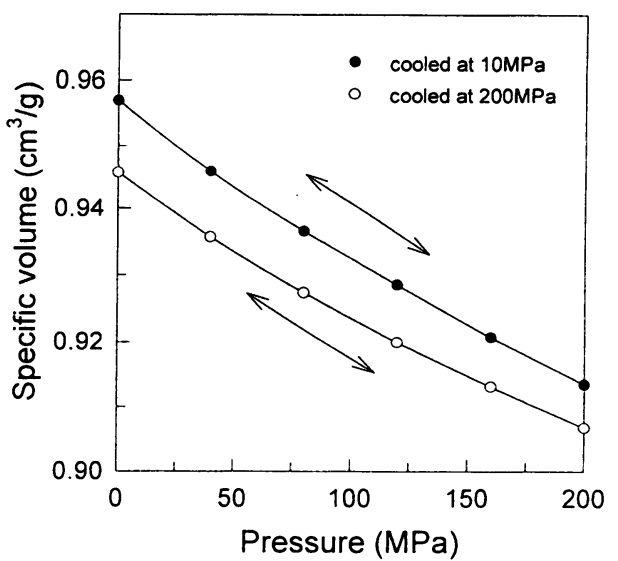

Fig. 7. Pressure dependence of specific volume in PS at $35{ }^{\circ} \mathrm{C}[4]$.

以上の比容積の差が生じている。この差は精密な成形 加工を行う上では無視できない大きさである。このガ ラスを $10 \mathrm{MPa}$ で昇温すると $(\mathrm{F} \rightarrow \mathrm{G} \rightarrow \mathrm{H} \rightarrow \mathrm{I} \rightarrow \mathrm{C})$ 、明らか に3つの屈曲点(G、H、I)が現れている。これは、高密 度ガラス(F-G)が異なる状態のガラス(H-I)に変化した 後に溶融状態となることを示している。溶融状態の $V-T$ 直線をガラス状態に外挿した線に近つくのではな く、10 MPa のガラスの挙動(H-I)に重なろうとするので ある。この図から、高圧下で冷却することにより得ら れた高密度化ガラスは、ガラス転移温度以下でも均一 化しながら測定圧力において疑似安定と考えられるガ ラスへと変化していくと考えられる。

Fig.7は、10および $200 \mathrm{MPa}$ で泠却して作製された ガラスの $35{ }^{\circ} \mathrm{C} て ゙ の ~ V-P$ 曲線を表している。加圧・減 圧により大きな変化がみられるが、この挙動はほとん ど時間に依存しない。つまり、圧力に対してかなりの 収縮を示すにもかかわらず、圧力を除去すると完全に 元の体積に戻ってしまう。これは、高分子液体と同様 の挙動である。さらに、200 MPaに $100 \mathrm{~h}$ 程度保持し ても比容積はそのままの值を保持する。高密度ガラス においても同じであり、高分子ガラスは $T_{g}$ から比較的 離れた温度では圧力に対してかなり弾性的であるとい える。また、この測定から等温モードでの測定の有効 性も妥当であるといえる。

以上のように、異なる冷却速度あるいは異なる圧力 でガラスを形成させた場合、異なるガラス状態が得ら れ、その挙動も大きく異なっている。精密成形を行う 場合、上記で示したことも考虑に入れる必要がある。 高分子ガラスの構造・ガラス化については古くから
多くの研究がなされてきたが、その複雑さゆえになか なか進展がみられなかったが、最近、理論・実験の側 面からの進歩が著しく[7,8]、さらに、コンピュータの 発達にともないシミュレーションについても興味ある 結果が出されている[9]。

\section{5. 结晶性高分子の結晶化・融解誉動}

Fig. 4 に直鎖状の PE（Mw=115K）の融解挙動を示 したが、 $T_{m}$ 前後で大きな体積変化が生じていることが よくわかる。ガラス転移挙動と異なり、 $T_{m}$ 前後で体皘 に飛びがあり、比容積が大きく変化する典型的な熱力 学の一次転移を示している。PEやポリプロピレン(PP) などの結晶性高分子は、室温で結晶部分と非晶部分が 共存している。結晶部分が占める分率を結晶化度とい いここの値が比容積に大きな影響を及ほす。結晶は、 高分子鎖が規則正しく配列された状態であることから、 比容積は溶融状態よりもかなり小さい。結晶性高分子 の $T_{m}$ 以下での比容積は、結晶化度・結晶形態により大 きく異なり、また、非晶の部分はガラス転移を起こす。 結晶化速度は、熱力学的因子によって大きく変化し、 冷却速度にも大きく影響を及ぼされることから、 $T_{m}$ 以 下での比容積は熱履歴に大きく左右される。

相転移の圧力依存性は、次式で示す ClausiusClapeylon の式により熱力学的に記述される。

$$
\frac{\mathrm{d} P}{\mathrm{~d} T}=\frac{\Delta H}{T \Delta V}
$$

ここで、 $\Delta H$ と $\Delta V$ は、それぞれ相転移のさいのエン タルピーと体積の変化量である。通常、結晶化に伴い $\Delta V$ が負になる場合は、王力の增加にともない $T_{m}$ が 增加する。 $\Delta H$ と $\Delta V$ は結晶形態に依存し、結晶化度 との関係も重要である。

Fig. 8 は、ポリテトラフルオロエチレン(PTFE)の相 図を示している[10]。压力と温度により様々な相転移 が現れている。柔軟な分子鎖を有する高分子からなる 結晶は、温度だけではなく圧力によってもいろいろな 結晶系・分子鎖形態を取りうるため、数多くの相転移 が出現する。これらの相転移点の圧力依存性は(1)式に よって説明づけられる。Fig. 9 は、Fig. 8 において縦の 点線で示されている圧力での相転移点近傍における体 積変化 $\Delta V$ を示している[10]。Fig. 9 に示されている相 転移でのエンタルピー変化の符号はすへて同じである ことから、相転移温度の圧力依存性の符号は、(1)式か ら $\Delta V$ の符号に従うことになる。予想通り、550 MPa での低温域での相転移では温度の上昇にともない体積 


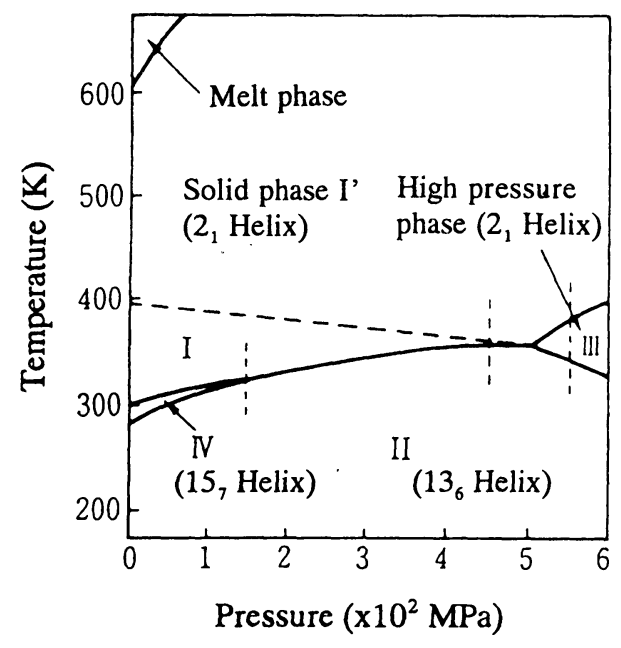

Fig. 8. Phase diagram of PTFE[10].

の減少（つまり、 $\left.\mathrm{d} T_{m} / \mathrm{d} P<0\right)$ がみられており、その他 では增加している。このように、 $T_{m}$ は圧力に大きく依 存することから、比容積も複雑な挙動を示し、その $P$ $V T$ 特性が重要となる。

\section{6. 高分子の状意方程式}

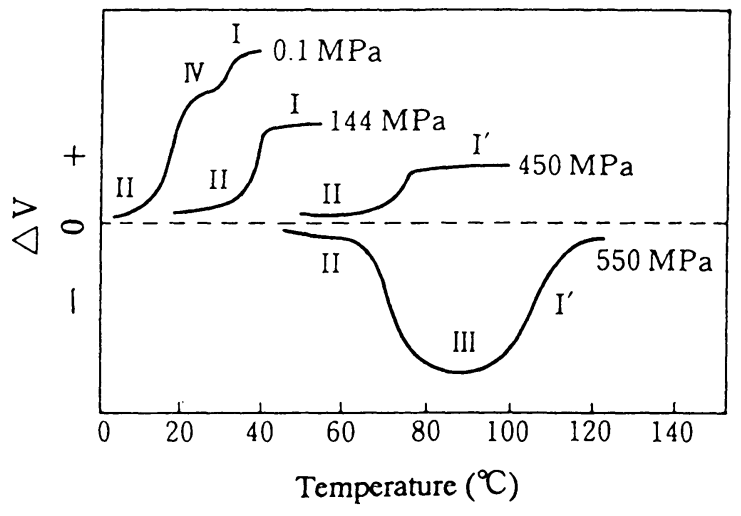

Fig. 9. Temperature dependence of volume change at some pressure in PTFE[10].

高分子の $P V T$ 関係を記述する状態方程式として 様々なものが提案されており、主なものを Table1 に示 す。これらのほとんどは、平衡状態である液体状態に つてのものである。

Tait の式は経験式であり、ガラスあるいは液体状態 それぞれについて常压での体積の温度変化 $\{V(0, T)\}$ を $T$ の多項式で正確に与え、 $B_{1}$ と $B_{2}$ を最小二乗法等によ

Table 1. Equations of state for polymers.

\begin{tabular}{|l|l|}
\hline Tait（ガラスおよび液体状態） & $V(P, T)=V(0, T)\left\{1-0.0894 \ln \left[1+\frac{P}{B_{1} \exp \left(-B_{2} T\right)}\right]\right\}$ \\
\hline Spencer-Gilmore[10] & $(P+\pi)(V-b)=\frac{R T}{M}$ \\
\hline (参考)van der Waals（換算式） & $\tilde{P} \tilde{V} / \tilde{T}=\frac{8 \tilde{V}}{3 \tilde{V}-1}-\frac{3}{\tilde{T} \tilde{V}}$ \\
\hline Flory[13] & $\tilde{P} \tilde{V} / \tilde{T}=\frac{\tilde{V}^{1 / 3}}{\tilde{V}^{1 / 3}-1}-\frac{1}{\tilde{T} \tilde{V}}$ \\
\hline Sanchez-Lacombe(SL)[14] & $\tilde{P} \tilde{V} / \tilde{T}=-\tilde{V}\left[\ln \left(1-\frac{1}{\tilde{V}}\right)+\left(1-\frac{1}{x_{p}}\right) \frac{1}{\tilde{V}}\right]-\frac{1}{\tilde{T} \tilde{V}}$ \\
\hline Cell Model(CM)[15] & $\tilde{P} \tilde{V} / \tilde{T}=\frac{\tilde{V}^{1 / 3}}{\tilde{V}^{1 / 3}-2^{-1 / 6}}-\frac{2}{\tilde{T} \tilde{V}^{2}}\left(1.2045-\frac{1.011}{\tilde{V}^{2}}\right)$ \\
\hline Modified Cell Model(MCM)[16] & $\tilde{P} \tilde{V} \tilde{T}=\frac{\tilde{V}^{1 / 3}}{\tilde{V}^{1 / 3}-1.07 \cdot 2^{-1 / 6}}-\frac{2}{\tilde{T} \tilde{V}^{2}}\left(1.2045-\frac{1.011}{\tilde{V}^{2}}\right)$ \\
\hline Simha-Somcynsky(SS)[17] & $\tilde{P} \tilde{V} / \tilde{T}=\frac{\left(y \tilde{V}^{1 / 3}\right.}{(y \tilde{V})^{1 / 3}-y 2^{-1 / 6}}-\frac{2 y}{\tilde{T}(y \tilde{V})^{2}}\left(1.2045-\frac{1.011}{(y \tilde{V})^{2}}\right)$ \\
\hline
\end{tabular}


り与えるとかなり実験結果をよく記述する。しかし、 この式は熱力学的な意味はなく、あくまでも経験的な 式である。

次に、Spencer-Gilmore の式は、実在気体に対して提 案された van der Waals の状態方程式と全く同じ形をし ており、実際の高分子の挙動を正確に記述することは できない。しかし、簡便であることから射出成形のシ ミュレーションに用いるなど、工業的には多く用いら れている。この他にも、実験結果に基づいて提案され たいくつかの経験式が用いられている[12,13]。

Flory から Simha-Somcynskyにいたる状態方程式は、 分配関数から熱力学的に求められたものである。これ らの式は、系固有の特性值を用いて換算された值 $(\tilde{P}$, $\tilde{V}, \tilde{T})$ を用いることによりすへての高分子に当てはめ ることができる。これらの式は、自由体積に関する表 現とセグメント間ポテンシャルのタイプの違いにより 異なる形を持つが形式的にはよく似ている。Table 1 に は、参考として van der Waals の状態方程式を換算値を 用いて書き換えたものを示したが、の式が Flory の式 とよく似ているのは、気体と液体の類似性によるもの と考えられる。これらの状態方程式のなかで、実際の 高分子の $P V T$ 挙動を最もうまく説明しうるのは、や や複雑な形をしているが、MCM と SS である。SS 理論 を用いてガラス状態に対して適用が試みられているが、 実際の挙動をうまく説明することはできていない。非 平衡状態に関する記述が難しいからであろう。また、 液晶性高分子に対する状態方程式も提案されている [19]。これらの状態方程式を用いて、分子鎖の性質や各 種の熱力学的挙動の説明が試みられている。 $T_{m}$ 以下の 結晶を含む状態については、結晶・非晶および結晶一 非晶界面領域が混在しており、状態方程式による研究 は全くなされていない。

CAE のシミュレーションにおいてもより精度の高い 状態方程式を用いることが望ましく、結晶状態は無理 としてもガラス状態（非平衡状態）までを含めた系統 的な状態方程式の出現が期待される。

\section{7. 成形加工と $P V T$ 举動}

上で示したように、高分子では温度と圧力の変化に 対して比容積が著しく変化することから、高分子を一 度溶融して固める成形加工には、 $P V T$ 特性がたいへ ん重要である。特に結晶性高分子は、Fig. 4 に示した PE の例のように非晶性高分子と比へて $T_{m}$ 前後で大き な比容積変化が生じるため、反り・引けが生じやすい。
このことは、成形加工工程の高度な制御が寸法精度の 向上には不可欠であること示している。しかし、結晶 性高分子の $T_{m}$ 以下での比容積は、結晶化度・結晶形態 により大きく変化することから、結晶化度と $P V T$ 挙 動の詳細なデー夕を知る必要がある。また、金型内で は、通常一定温度で結晶化させるわけではないので、 冷却速度と結晶化速度の関係が重要となる。これに、 圧力の効果も加わるので、これらすへてを含めた詳細 な検討が必要である。つまり、金型に高分子を充填す るさいの樹脂温度の経過亡保圧力の大きさとその持続 時間の関係が重要である。例えば、Fig. 4 からもわかる ように高圧ほど $T_{m}$ 前後での比容積の差が小さいことか ら、樹脂全体が $T_{m}$ 以下まで泠却されるまで大きな保圧 力を負荷することにより結晶化による体積変化が小さ い経路を選ぶといったことが重要になる。結晶化度の 違いによる比容積の変化を考虑していないが、Fig.10 に示したように $P V T$ 関係を三次元的に表わした状態 曲面を用いて、成形加エプロセスを検討するのも有用 である。

以上のことを行うためにも、 $P V T$ の関係が必要て あり、研究の広がりとともにデータの蓄積が現在進ん でいるが、まだ、不十分である。また、測定法による 差も存在しており、問題は多い。精密成形が十分可能 となるためには $P V T$ 挙動を考虑した金型設計、操作 条件の設定が必要となる。成形収縮率をいかに押さえ るか、あるいは、成形品の寸法のばらつきをいかにお さえるかが重要である。状態方程式に関しても、より 高分子の挙動をうまく説明しているものを用いるへき である。

また、材料の立場から考えると、分子量が大きくな

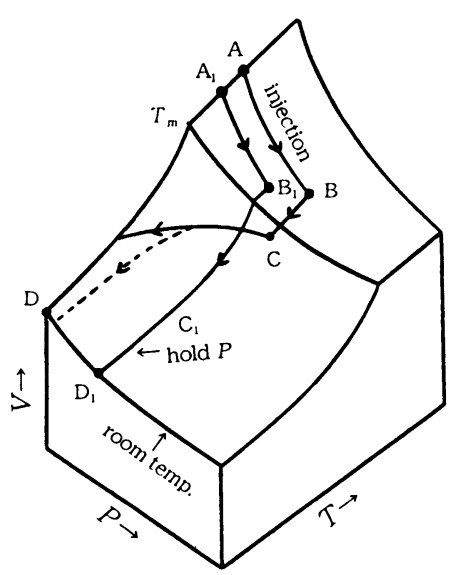

Fig. 10. 3 Dimensional PVT surface and processing in cry stall ine pol ymer[20]. 


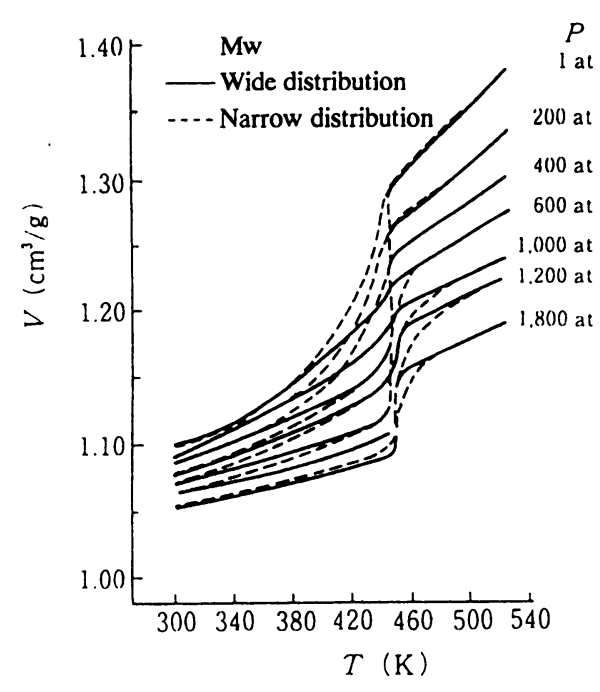

Fig. 11. $P V T$ behavior of $\mathrm{PP}[21]$.

ると $T_{m}$ がほとんど変化しなくなるが、結晶の融解にお ける比容積の挙動は分子量分布の影響を受ける。Fig.11 に分子量分布の違いによる $P V T$ 挙動の変化を示した。 $T_{m}$ 近傍で差があることがわかる。分子の流動特性など がPVT挙動に影響を及ほしていると考えられる。結 晶化速度に関しては、結晶化促進剂などの使用により これを制御し、成形加工に適した材料を用いることも 必要である。

実験的検討には限界があるので、物理的なモテルを 構築してシミュレーションによる評洒が、最近行われ るようになってきた。引け・反りを最小にするため最 適な冷却過程をコンピュータシミュレーションにより 求めるシステムも開発されつつある。そのためにも、 正確な $P V T$ 挙動のデータベースが必要亡なる。

\section{8. まとめ}

以上、実際の高分子の $P V T$ 挙動を基にして、い かに正確なテータが必要かを述へてきた。現時点で は、测定法による差も存在しており、問題点は多い。 より精密な測定や、様々な角度からの测定も必要と なるであろう。さらに、これまでの現象論的な取り 扱いのみならず、分子レベル、結晶レベルでの予想 が可能となるような理論的、実験的さらには CAE レ ベルでのさらなる研究の進展が望まれる。

\section{考文胡}

[1] 佐藤貞夫 : 第 3 回プラスチック成形加工基礎セミ ナーテキスト(1992)、“ポリマーのPVT特性とそ の計測の基礎" .

[2]Gnomix 社

[3]戒能憲幸、有吉秀穂 : 成形加工'91、175-176(1991)、 “ $P V T$ 測定一新型 $P V T$ 測定装置の特性” .

[4]著者、未発表デー夕.

[5]T.Ougizawa, G.T.Dee, D.J.Walsh: Polymer, 30, 1675-1679(1989), "PVT properties and equations of state of polystyrene: molecular weight dependence of the characteristic parameters in equation-of-s tate theories".

[6]萩原和将、B.Rudolf、扇澤敏明、井上隆：高分子学 会予稿集、45, 833(1996), “ $P V T$ 測定による高分子 ガラスに関する熱力学的研究”.

[7]川崎恭治 : 日本物理学会誌、48, 870-877(1993), “ガ ラス転移とモード結合理論”。

[8]例えば、高分子学会予稿集、44,1765-1827(1995), “ガラス状態およびガラス転移”。

[9]R.-J.Roe, M.Mondello, H.F uruya, H.-J.Yang: Macromolecules, 28, 2807-2818(1995), "Molecular dyn amics simulation of atactic pol ystyrene. 3. Short range order".

[10]松重和美、船津和守：「高分子の熱物性」、共立 出版、1995 年.

[11] R.S.Spencer, G.D.Gilmore: J.Appl.Phys., 20, $502-$ 506(1949), "Equation of state for polystyrene“.

[12] H.Breuer, G.Rehage: Kolloid z-z.Polym., 216, 159-179 (1967), "Zur Thermodynamik der glasigen erstarrung“.

[13] N.Kamal, N.Levan: Polym.Eng.Sci., 13, 2-8(1973), "Equation of state for polymers".

[14] P.J.Flory, R.A.Orwoll, A.Vrij: J.Am.Chem.Soc., 86, 3507-3514(1964), "Statistical thermodynamics of chain molecule liquids. I. An equation of state for normal paraffin hydrocarbons".

[15] I.C.Sanchez, R.H.Lacombe: J.Phys.Chem., 80, 23522362(1976), "An elementary molecular theory of classical fluids. Pure fluids".

[16] G.T.Dee, D.J.Walsh: Macromolecules, 21, 811815(1988), "Equations of state for polymer liquids".

[17] G.T.Dee, D.J.Walsh: Macromolecules, 21,815817 (1988), "A modified cell model equation of state for polymer liquids". 
[18] T.Somcynsky, R.Simha: Macromolecules, 2, 342350(1969), "On the statistical thermodynamics of spherical and chain molecule fluids".

[19] D.J.Walsh, G.T.Dee, P.W.Wojtkowski: Polymer, 30, 1467-1471(1989), " $P V T$ properties of main-chain liquidcrystalline polymers".
[20] 大楖康 : 第 2 回プラスチック成形加工基礎セミ ナーテキスト(1991)、“成形加工の基礎特性と問題 点”.

[21] 伊東公正編 : プラスチックテータハンドブック、 工業調查会、p.26(1980).

[1996 年9月 30 日] 